\title{
Factors influencing the internationalization of small-sized textile firms in a Small Island Developing State: A Mauritian study
}

\author{
Rajesh Sannegadu \\ University of Mauritius, Mauritius \\ r.sannegadu@uom.ac.mu
}

\author{
Alfred Henrico \\ North West University, South Africa \\ alfred.henrico@nwu.ac.za (corresponding author) \\ Louis van Staden \\ North West University, South Africa \\ louis.vanstaden@nwu.ac.za
}

\begin{abstract}
Internationalization offers opportunities to small firms in small island developing states for market growth, sustainability, reduced dependency on local markets, and economies of scale. As small- and medium-sized enterprises (SMEs) are increasingly playing a significant role in many countries' socioeconomic development, Mauritian-based textile manufacturers are seen as an engine of growth for the Mauritian economy by attracting foreign direct investment, subsequently creating jobs and strengthening the manufacturing base of the economy. In this regard, the contribution of the textile industry in transforming the Mauritian economy from a middle-income economy to a high-income economy is widely acknowledged. However, most of the small- and medium-sized Mauritian textile manufacturing firms are currently not internationalized and face several domestic survival and sustainability challenges resulting from the liberalized trading system adopted by the Mauritian government in 2005. In this article, we investigate firm size-related factors, which influence small textile manufacturers' internationalization intentions. We argue that factors relating to financial and non-financial resources are the main causes discouraging small firms' internationalization. These factors emerged from interviews with ten internationalized medium-sized textile manufacturers in Mauritius that overcame their size-related barriers. We further extended the research by surveying the whole population of internationalized medium-sized textile manufacturers in Mauritius for triangulation purposes.
\end{abstract}

Keywords: developing markets, foreign market entry, internationalization theories, Mauritius, small- and medium-sized enterprises (SMEs), Small Island Developing States (SIDS), textile manufacturing

https://doi.org/10.24043/isj.154 • Received August 2020, Early access February 2021

(C) Island Studies Journal, 2021 


\section{Introduction}

In Small Island Developing States (SIDS), firms focusing only on their domestic markets for survival and growth often experience severe competition and limited growth opportunities, especially when markets are saturated with homogenous product offerings (World Bank Group, 2019). One such Small Island Developing State, Mauritius, has been experiencing extreme competitive forces in its textile manufacturing industry since 2005 , due to trade liberalization and an upsurge of cheap substitutes, imported predominantly from Asian countries (Mauritius Export Association [MEXA], 2017). Many locally based firms have since begun attempts to expand their operations beyond their national borders, and while a few firms have attained the objective of becoming truly global, most have been less successful in their international ventures. These firms often find it difficult to conduct cross-border transactions (Organization for Economic Co-operation and Development [OECD], 2011), due to factors such as limited capital (Vemic, 2019); lack of managerial time, skills, and knowledge (Calcagnini \& Favaretto, 2012); the inability to contact potential mainland overseas customers; as well as frequent changes in international rules and regulations (OECD, 2009). Since these factors are more prevalent in SIDS-based small firms, it is perceived that the size of firms, as determined by their financial, physical, or human size, plays a crucial role in their intentions and abilities to internationalize (Jaklič \& Svetličič, 2017). Compared to smaller firms, it is arguably easier for larger firms to internationalize, since they have better access to resources and more national and international outreach abilities (Balboni et al., 2013; Coe \& Jones, 2010; Jaklič \& Svetličič, 2017). However, this argument is based on most research studies being conducted in developed countries. Although small island states have been the subject of a great deal of research over the years (Baldacchino et al., 2008), there is a dearth of research regarding insights of the factors influencing the internationalization of small- and medium-sized enterprises (SMEs) in SIDS. Therefore, this article aims to fill an apparent current research gap by identifying the factors influencing SIDS-based firms' internationalization intentions, specifically in the textile manufacturing industry in Mauritius.

The Mauritian textile manufacturing industry has been instrumental in the transformation of the Mauritian economy from a single crop sugar-dominated economy to a service-driven economy over the past four decades (MEXA, 2017). For many years, the textile industry has been an engine of growth for the Mauritian economy by attracting foreign direct investment, subsequently creating jobs and strengthening the manufacturing base of the economy. According to the Ministry of Finance and Economic Development (2018, p. 34), the number of people employed in this sector in 2018 stood at 47,100 and the industry contributed 55\% to the total of all Mauritian exports, mainly to Europe, the United States of America (USA), and South Africa (MEXA, 2017, p. 38). However, the dismantlement of the Multi Fibre Agreement (MFA) in 2005, the influx of low-cost foreign manufacturers, increased domestic labour costs, the shortage of domestic labour, high energy and transportation costs, and the prolonged European economic crisis have negatively influenced the international competitiveness of the Mauritian textile industry, with exports dropping from 8\% in 2016 to 7\% in 2017 (MEXA, 2017). Nevertheless, the Mauritian textile industry is recognized as a textile hub of excellence in South-Eastern Africa, which also presents export and growth opportunities for Mauritian-based textile manufacturing firms (Enterprise 
Mauritius, 2017). Moreover, the Mauritian membership in different trading blocs allows local textile manufacturing firms to enter new regional markets at lower costs through the reduction in tariff and non-tariff barriers.

In light of opportunities that internationalization presents for the SME sector in Mauritius, and for SIDS economies in general, it is not surprising that the promotion of SMEs features prominently in the government agendas of many countries around the world. Thus, this study serves as a pioneer study to broaden one's understanding towards the factors influencing the internationalization of small- and medium-sized textile firms in a Small Island Developing State. Findings of the study are useful to policy makers of SIDS to effectively facilitate these firms' growth and entrance into international markets. Moreover, noninternationalized SMEs in island states may refer to the findings of this study to effectively strategize their international growth. The theoretical findings will also contribute to the contemporary body of empirical and conceptual knowledge by providing updates to the existing work of other researchers and scholars and, thus, adding new contributions to the body of knowledge pertaining to internationalization of SMEs in SIDS economies.

This article commences with the theoretical context underpinning this research, and subsequently continues with an explanation of the research design, followed by the presentation of the results. Finally, we will discuss the conclusions that can be drawn from the results.

\section{Internationalization}

Existing literature provides a myriad of definitions of internationalization. For the purpose of this article, we reviewed and analyzed 22 definitions of internationalization spanning almost 60 years of research from various internationalization approaches, models, and theories. From the analysis of the definitions, we concluded that internationalization constitutes three main attributes, namely: (i) cross-border operations relate to firms' growth strategies, (ii) internationalization is a process, and (iii) knowledge and access to international networks are important considerations. Combining these three attributes, internationalization can holistically be defined as a growth strategy that firms implement when they follow a process to expand their operations across country borders. According to Lakew (2015), internationalization theories and models often aim to explain why (motives) and how (modes of entry) firms engage in cross-border operations. Internationalization motives can be either internal or external in nature. Internal motives represent the internal strengths or weaknesses within firms, such as available resources and financial stability, that drive firms towards internationalization, whereas external motives emerge from firms' external environments in the form of opportunities on which they can capitalize or threats they should avoid (Dominguez \& Mayrhofer, 2018; Rodtook \& Altinay, 2013). In addition, the internal and external motives are either proactive or reactive in nature. Proactive motives refer to management's inherent aspirations to conduct international transactions, while reactive motives imply that managers portray passive behaviors and initially have no interest in international sales, but are prepared to react to unsolicited orders (Hollensen, 2014). According to Vazquez-Brust, Sarkis, and Cordeiro (2013), SIDS-based SMEs are primarily reactive towards internationalization, whereas SMEs from developed countries are more proactive. The reactive motives of SIDS-based SMEs can be explained by the fact that they face many barriers (such as the lack of financial and other resources) which prevent them from 
initiating international development or hinder their involvement in the internationalization process. This is also the case in Mauritius as a SIDS, where SMEs are mostly reactive and externally motivated to internationalize due to their perceived resource limitations, the smallness and saturation of the local market, as well as the liberalization of trade.

Following the motivation to internationalize, managers also need to decide on how they intend to enter the foreign markets (Ferreira et al., 2013; Olejnik, 2014). According to Hamilton and Webster (2015) as well as Laufs and Schwens (2014), firms can internationalize by following either an equity mode, a non-equity mode, or a combination of these modes. However, Gubik and Karajz (2014), Jones et al. (2009), Karasavvoglou and Polychronidou (2017), Kellermanns and Hoy (2016), as well as Ruzzier and colleagues (2007) found that SMEs would rather follow a non-equity mode of entry into foreign markets, in particular exportation, during their initial internationalization ventures. Exports are traditionally the most established mode of entry into international markets (Fernandez-Olmos \& D'iez-Vial, 2013; Hopkins, 2017) and entail the domestic production of goods, which are then distributed across borders (by land, sea, or air) to be sold in foreign markets (Hill, 2017). For a SIDS such as Mauritius with its unique SME landscape, exportation is considered as a minimum risk, feasible, and convenient strategy in situations where firms do not have sufficient knowledge of the foreign markets (Narayanan, 2015).

\section{The relationship between the size of firms, capabilities, and internationalization}

The relationship between size and internationalization has been widely discussed in international business literature (Balboni et al., 2013). For example, based on the review and evaluation of 52 articles published between 1998 and 2005 to assess the determinants of export performance, Sousa, Martínez-López, and Coelho (2008) found that firm size was the most researched independent variable. More recently, Chen, Sousa, and He (2016) confirmed that the relationship between firm size and effective export performance continued to receive a lot of attention from researchers in the period from 2006-2014.

The relationship between firm size and international behavior is closely associated with Penrose's (1959) seminal work, which considers a firm's size as a proxy of resource availability. Penrose's (1959) theory was later used to develop the modern resource-based view (RBV) theory in strategic management (Mitomo et al., 2015). The resource-based view, which was conceptualized by Barney's (1991) theory of business resources and sustained competitive advantage, proposes that a firm is a bundle of unique capabilities or resources that have an important role in enabling or constraining organizational growth. According to Barney (1991), heterogeneity among firms in owning and controlling key resources is perceived as a fundamental driver for creating and maintaining a long-term sustainable competitive advantage, which in turn supports international involvement. The RBV theory has been applied in several studies on firms' internationalization (Lakew, 2015). These studies have used firm size as a predictor for their capabilities, since it is assumed that as firms grow their capabilities also increase, which ultimately supports their internationalization (Balboni et al., 2013). In support, an analysis of 247 internationalized Slovenian SMEs by Ruzzier and Ruzzier (2015) revealed that internationalized firms are significantly larger and have more specialized resources (human, organizational, and financial) than non-internationalized firms. 
Moreover, since innovation capabilities depend significantly on the firm's existing resources (as determined by its size), SMEs tend to postpone innovative projects due to high financial expenses (Archer et al., 2020). Several studies, including Aghion et al. (2012), García-Quevedo, Segarra-Blasco, and Teruel (2018), and Silva and Carreira (2012), have recognised that financially constrained SMEs are not likely to be enthusiastically innovative. Nevertheless, the relationship between innovation and credit constraints is not always negative, as evidenced by Archer, Sharma, and Su's (2020) study, which revealed that financially constrained Vietnamese SMEs are more innovative than unconstrained firms. Given the high cost implications, SMEs tend to adopt incremental innovation (i.e., product or service improvements) instead of radical innovation (i.e., new product or service) (Xin et al., 2019). Innovation is key for the sustainability of the textile manufacturing industry as it engenders better performance in the foreign markets by keeping up-to-date with fashion trends and the latest production techniques.

Additionally, studies by Alvarez (2004), Maumbe and Okello (2013), Singh (2009), as well as Tang (2011) present size-related attributes as one of the most significant factors limiting SMEs' ability to internationalize. The smallness of SMEs poses challenges in terms of scarcity of capital, technology, expertise, and human resources (Das, 2015). According to Kalinic and Forza (2012), SMEs must rely on intangible assets, such as managers' knowledge and networking skills, to develop competitive advantages in the local and foreign markets. For example, a firm's existing body of international market knowledge is one of the most valuable, rare, and difficult-to-imitate intangible resources that new ventures can use to leverage in their international endeavors (Kalinic \& Forza, 2012). This knowledge, as well as managers' negotiation skills gained through international experience in the form of education or work experience, enables firms to reduce the search and negotiation costs associated with foreign transactions (Peng, 2001). According to Reddy (2007), the development of SMEs in island states depends significantly on the network linkages. These linkages provide extra resources that affect firm growth in several ways, such as mobilizing resources quickly and obtaining market information at the lowest cost.

However, being resource constrained, many SMEs are reluctant to increase their commitment to internationalize (Ruzzier \& Ruzzier, 2015). Moreover, since small firms are not simply scaled-down versions of larger firms, they differ from larger firms in their managerial style, independence, ownership, and scale/scope of operations (Kyvik, 2011). Linder and Leyh (2018) further note that SMEs are often seen and described as being more agile and flexible than larger firms, which would enable them to absorb market change more easily and with less effort.

A small island state has its own particular identity, business ecosystem, and socio-cultural context that influences SME internationalization. For example, Baldacchino, Cassar, and Caruana (2008) identified several island-specific factors directly influencing the entrepreneurial intention of Maltese SMEs. These factors included openness to new ideas, reputation and fear of failure, strong family values, personal contacts and social networks, the enterprise environment, creativity, and innovation. In a similar vein, Singh, Pathak, and Naz (2010) note that several factors - including access to finance, transportation, weak domestic markets, business-related regulatory and legal impediments, inadequate knowledge of foreign sales practices, and lack of entrepreneurial capacities and skills - affect the internationalization process of SMEs in island states such as Fiji and Samoa. Furthermore, given that small island 
states are often resource constrained, these challenges are more likely to affect SMEs' propensity to internationalize their firms.

\section{The Mauritian SME landscape}

According Madani (2018), there is no universal or globally accepted definition of what constitutes an SME. A review of several definitions of SMEs for the purpose of this article revealed that different quantitative measures have been used to classify firms as SMEs, such as the number of employees, turnover, and firms' net worth (balance sheets). However, Madani (2018) notes that the reference to a firm as an SME has always varied according to countries' applied legislation. In Mauritius, a 'small enterprise' is defined as a firm which has a turnover of less than Rs10 million (approx. US $\$ 277,778$, based on the exchange rate of $1 \mathrm{US} \$=$ Rs 36 ), while a 'medium enterprise' is a viewed as a firm with an annual turnover of more than Rs10 million and less than Rs50 million (approx. US\$1,388,88) (Small and Medium Development Authority, 2009).

To determine the factors influencing small-sized firms' internationalization intentions in SIDS contexts, we focused on medium-sized textile manufacturers in Mauritius. Being one of several industries in Mauritius, the textile manufacturing industry has played an important role in the transformation of the Mauritian economy from a single crop sugar-dominated economy to a service-driven economy over the past four decades (MEXA, 2017). This industry has been one of the major catalysts of the so-called "Mauritian Industrial Revolution" (Economic Development Board [EDB], 2018). For several years now, the textile manufacturing industry in Mauritius has been acting as the engine of growth for the economy by attracting foreign direct investment (FDI), subsequently creating jobs and strengthening the manufacturing base of the economy. Moreover, according to the Mauritian Ministry of Business, Enterprise, and Cooperatives (MBEC; 2018), this industry plays an important role in transforming Mauritius from a middle-income country into a high-income country, as envisioned by the Mauritian government. However, the textile manufacturing industry has been facing several challenges following the introduction of the liberalized trading system in 2005. In the domestic market, competitive pressures from low-cost manufacturing countries, such as China and India, have been threatening the survival of textile manufacturers, while in the foreign markets their competitiveness is being challenged due to an increase in the cost of production (MEXA, 2017).

As in many economies around the world, SMEs are also important contributors to the Mauritian economy. Moreover, the pressure to internationalize is being felt more among these firms, since they are more vulnerable to the influence of external forces (Caiazza \& Volpe, 2013; Shafaeddin, 2014). On the other hand, several opportunities exist for Mauritian medium-sized textile manufacturers to be sustainable, especially in African markets and some European markets (EDB, 2018). However, the question remains whether the size of firms limits their internationalization intentions, since it is argued that size-related factors are the main determinants of SMEs' (in)ability to grow and compete internationally (Chen et al., 2016).

In support of SMEs' export initiatives, the Mauritian government developed the National Export Strategy (NES) in 2017 with the aim of transforming the country into an export-driven economy. The timespan for the implementation of the NES was from 2017 to 2021, and this strategy provides guidelines for the enhancement of export competitiveness, institutional support from both private and public institutions, and relevant and accessible 
trade support services (NES, 2017). Although the island showed increased export activities since 2017, the global COVID-19 pandemic in 2020, as with most countries worldwide, influenced Mauritian international trade negatively. Despite an increase of $71 \%$ in total exports in May 2020 compared to the previous month, exports were still 40.2\% lower than in May 2019 (Statistics Mauritius, 2020). Mauritian exports were, therefore, starting to regain momentum to major export destinations - which included the United Kingdom (13.3\%), Italy (9.7\%), France (8.8\%), and the USA (8.6\%) — in May 2020 (Statistics Mauritius, 2020).

\section{Problem statement}

The challenges faced by a SIDS like Mauritius have a greater limiting effect on the scope for international expansion of SMEs as compared to large firms from developed countries which have a different set of resources and experiences (The World Bank Group, 2019). Although firm size is considered as one of the main determinants influencing SMEs intentions to internationalize, it is unclear if this argument also holds for textile manufacturing SMEs in Mauritius, or which size-related factors might influence these firms' internationalization intentions. Against this backdrop, this article aims to determine which size-related factors influence the internationalization intentions of Mauritian-based textile manufacturing SMEs.

\section{Methodology}

The design and methods according to which the study was executed, as well as procedures for data analysis, are presented below.

\section{Research paradigm}

The ontological stance we adopted for this research can be described as pragmatic and it enabled us to use a mixed-methods approach to achieve the set objectives. Moreover, the mixed-methods approach allowed us to use the findings from one method to inform the other method, thereby strengthening the trustworthiness and validity of the research (Onwuegbuzie \& Collins, 2017). According to Creswell and Plano Clark (2017), an exploratory sequential mixed-method approach enables researchers to implement both methods sequentially, starting with the qualitative data collection and analysis, followed by the quantitative data collection and analysis. For the purpose of this research, an exploratory sequential mixed-method approach (QUAL/quan) was applied in which the qualitative approach was used as the main approach for data collection. The qualitative data was then used to develop the instrument which was used to gather the quantitative data.

\section{Population and sample}

In 2018, the number of SMEs in Mauritius was estimated at around 172,200, contributing $40 \%$ of the Gross Domestic Product (GDP) (Statistics Mauritius, 2018). Only 1\% of these SMEs, across all economic sectors, are medium-sized (approximately 1,722), with small-sized firms constituting $99 \%$ of SMEs. Of these estimated 1,722 medium-sized firms, only $9 \%$ (approximately 155) are operating in the textile manufacturing industry, however only 90 of the estimated 155 medium-sized textile manufacturers were registered with the Mauritian Ministry of Industry and Commerce as serving international markets in 2019. Further 
investigation into the databases of SME Mauritius, Mauritius Export Association (MEXA), and the Ministry of Industry and Commerce revealed that only 56 of these 90 registered firms were still in operation in 2019, which led to a population size of 56 Mauritian medium-sized textile manufacturers.

Qualitative sample. From the population, non-probability purposive sampling was used to identify the participants for the qualitative data collection. These participants were not chosen by chance (Ary et al., 2019), but in accordance with their location, status, position, and agreement (Schwester, 2015). Although Patten and Newhart (2018) argue that qualitative sample size has been a contentious issue since the acceptance of qualitative research methods, we agree with Creswell and Creswell (2018) that an adequate qualitative sample depends on data saturation. We therefore collected data up to the point where questions did not provide new information, hence data saturation (Fusch \& Ness, 2015). For the purpose of this study, ten medium-sized textile manufacturers were sampled for qualitative data collection. Although we reached the saturation point after the sixth interview, we proceeded to conduct fouradditional interviews in order to validate the point of diminishing return.

Quantitative sample. Since most current medium-sized textile manufacturers started as small firms, all medium-sized textile manufacturers in Mauritius were sampled for quantitative data collection (Babin \& Zikmund, 2016).

\section{Data collection}

To collect data, we used a combination of an exploratory research design and a descriptive research design. For the purpose of exploratory research, we used qualitative interviews to explore the internationalization of medium-sized textile manufacturers in depth, since there is not an abundance of information available about the internationalization processes of these firms (Kolb, 2017). Furthermore, based on the information we gained from the interviews, descriptive research by means of a questionnaire enabled us to validate and extend the findings of the qualitative data (Bukve, 2019; Malhotra, 2010).

Qualitative data collection. All the participants who were sampled for qualitative data collection were individually contacted and invited to participate in the interviews. Those who agreed to be interviewed were made aware of the purpose of the research, the different themes that would be addressed during the interview, and how we would collect, disseminate, and store the collected data. Moreover, they were informed that their participation in the interviews was voluntary and that they could withdraw from the research at any stage during their interviews. Those participants who gave their consent were reassured that the information gathered will be treated in a strictly confidential manner and reported anonymously (O'Keeffe et al., 2016).

Quantitative data collection. To collect the quantitative data, we enlisted the assistance of business development officers employed by SME Mauritius, which enabled us to contact all 56 internationalized medium-sized textile manufacturing firms. These respondents were all contacted individually and presented with the rationale for the research. While some respondents readily accepted to participate in the study, a few were reluctant to provide their inputs. Subsequently, appointments were made with respondents who agreed to contribute to this study and arrangements were made to administer the questionnaire at their firms' premises. In some cases, however, the respondents requested to receive the questionnaire by mail with no personal contact. While the majority of the respondents completed the 
questionnaire and returned it the same day of the appointment, a small number of respondents returned the completed questionnaire a few days later. In allowing these respondents sufficient time to complete the questionnaire, they were given more time to study the questions; this was also identified as a strategy to reduce any biases which may be related to time restrictions.

Data analysis

We used specific data analysis methods to organize, provide structure, and to elicit meaning from both the qualitative and quantitative the data collected (Polit \& Beck, 2012, p. 507; Profetto-McGrath et al., 2010). This enabled us to transform the raw data into meaningful information, which we used to draw conclusions and make recommendations (Shazia, 2014).

Qualitative data analysis. We adopted the qualitative data analysis process identified by Sekaran and Bougie (2016), which they based on the approach by Morse and Field (1996). This approach comprises four steps, namely the (1) comprehension; (2) synthesis; (3) theorizing; and (4) re-contextualizing of data. Prior to data analysis and coding of the data, the transcriptions of the interviews were adequately prepared and checked for accuracy by comparing the transcripts with the original recordings. The coding of each transcript was done by using the line-by-line analysis approach recommended by Morse and Field (1996). The ATLAS.ti 8 qualitative data analysis software was used to code the collected data and to apply categorical analysis to identify relevant categories and themes.

Validity and reliability are key aspects in research, and more so in qualitative studies, since such research findings are often questioned or viewed with skepticism by the scientific community due to its subjectivity (Brink, 1993). According to Maree (2016), the reliability and validity of qualitative interview data depend on the trustworthiness of the data, the method as a whole, and its execution. In short, trustworthiness simply poses the question, "Can the findings to be trusted?" To ensure the trustworthiness of the qualitative data in this study, we scrupulously applied four criteria - credibility, transferability, dependability, and confirmability — as proposed by Bezuidenhout (2005), Korstjensa and Moserb (2018), Morse and colleagues (2002), as well as Shenton (2004). The methods we used to establish trustworthiness included member checking, prolonged engagement, peer debriefing, direct quotations, audio recordings, transcription of interviews, and reflexivity. Member checking was implemented by returning the interview transcripts to some of the participants, which allowed them to rephrase their narratives by omitting certain extracts which they may feel no longer represent their experiences or may present them in a negative light. Concerning prolonged engagement, we were immersed in this research for more than three years, which enabled us to gain sufficient knowledge to make informed decisions based on applicable literature sources and our exposure to the context of this research. Peer debriefing was implemented by submitting all findings and interview transcripts to experienced qualitative researchers for validation purposes. Reflexivity was achieved when any biases whilst conducting the in-depth interviews were overcome by maintaining a neutral stance and not introducing personal perceptions and/or interpretations during data collection.

Quantitative data analysis. Within this mixed-methods approach, the quantitative data was gathered in support of the qualitative data. Extensive statistical analyses were not within the scope of this research; rather, the aim was to gather as much information as possible to contribute to the purpose of this research. The analyses of the quantitative data collected were conducted with the Statistical Package for the Social Science (SPSS) program, version 25. 
The analyses commenced with the psychometric properties of the questionnaire. In this regard, the reliability of the measuring scales was assessed by means of reliability statistics (Cronbach's alpha), and an exploratory factor analysis was conducted to contribute towards the validity of the questionnaire. The respondents' demographics and patronage habits were also analyzed in terms of the firms' turnovers, number of years in operation, and their main export markets, among others. In addition, descriptive statistics were calculated for each of the items relating to the influence of size in their internationalization decisions. To organize the findings, we decided to report the qualitative and quantitative findings separately and then triangulate elements which emerged from both methods.

\section{Qualitative findings}

The ten participants involved in the qualitative data collection mainly varied in terms of the number of workers they employ, their years in operation, and the number of years they have been involved in international markets. All of the participants indicated that they started as small firms when they were first established and progressively expanded into medium-sized firms after they internationalized their operations. In this regard, all of the participants currently employ between 30 and 95 workers. Most of the participants have been in operation between 8 and 16 years, and only one participant has been in operation for more than 30 years. Most of the participants have also been involved in international markets between 3 and ten years, with only one participant involved in international markets for more than 25 years.

Based on the qualitative findings, several themes linking the size of the firms to internationalization intentions emerged: initial internationalization intentions, financial resources influencing internationalization decisions, and non-financial resources influencing internationalization decisions, with the latter being further categorized into three sub-themes.

\section{Theme 1: Initial internationalization intentions}

Despite the majority of the firms being established after the turn of the century, during the time when "born globals" were seen as the new way of internationalization, most of the participants indicated that, due to their small size, they did not initially have any intentions to internationalize when they were first established as small firms. However, their participation in buyer-and-seller meetings, such as the SME Mauritius international trade fairs, led to unsolicited orders from foreign clients. These unsolicited orders ultimately motivated them to investigate and expand into international markets. Subsequently, due to the small Mauritian local market and the growth opportunities presented by internationalization, they continued to expand internationally rather than nationally. From the participants' opinions, it can be deduced that they have a positive perception towards internationalization, since they feel that they have much to gain in terms of exposure, revenue, and market development. Despite the opportunities presented to them through unsolicited orders, they were all initially reluctant to internationalize, mainly due to their size-related financial and non-financial resource limitations. Based on the findings of the qualitative study, it can be deduced that these firms are driven towards internationalization by reactive motives. This result is aligned with the findings of Vazquez-Brust, Sarkis, and Cordeiro (2013), who asserted that SIDS-based SMEs are primarily reactive towards internationalization. 
Theme 2: Financial resources influencing internationalization decisions

The majority of the participants indicated that the availability of finance was a major factor influencing their initial decisions to internationalize, with some revealing, "we faced some difficulties in financing our first international transactions" and "we needed working capital to start production and to meet foreign order in a timely manner." One of the most prominent financial challenges that participants experienced was the time it took clients to settle their accounts. These actions had a profound impact on their available working capital, which also limited their scope for further expansion and international growth. This, however, did not discourage their export decisions and, to overcome financial burdens, all of the participants indicated that they sought financial assistance (in the form of short- and long-term loans) from retail banks: "We obtained loans without much difficulty." These loans were secured by fixed charges on collaterals. Moreover, on top of investing their savings, participants also used their profits to finance their internationalization.

Furthermore, it can be deduced from the participants' responses that financial assistance from their retail banks was not difficult to obtain during the initial stages of their internationalization. However, certain conditions had to be met before any assistance was granted to them. For example, they had to have sufficient collaterals to cover the amount of their loans, have repayment capacity (orders at hand to generate future streams of income); meet the retail banks' requirements, and have good working relationships with their retail banks.

Although the participants indicated that their financial situations due to their small size initially had a negative influence on their decisions to internationalize, the ease with which financial assistance was obtained positively influenced their decisions to initiate and pursue international transactions: "It was fairly easy to obtain loans, which motivated us to engage in foreign markets." They further revealed that the financial assistance they obtained not only allowed them to match the gap in working capital, but also allowed them to (i) "sustain low seasons," (ii) "honor financial obligation," and (iii) "invest in new equipment."

In addition to the financial support they received from their retail banks, the Mauritian government also provides financial support to SMEs' internationalization efforts in the form of loans and monetary incentives (MBEC, 2018). However, the majority of the participants deplored the administrative hurdles they had to overcome to secure government financial support. This discouraged them from benefiting from the support provided under the government's funded schemes, as many revealed that they "have not sought any such support" and preferred to "draw their own paths in the international market."

The present results are consistent with Shariff, Ahmad, and Shabir's (2020) study which identified difficulty in accessing finance as a major impediment to SMEs' performance and internationalization. Moreover, several studies, including Kruasom (2017), have concluded that lack of finance may prevent SMEs from building competitive advantage among themselves.

\section{Theme 3: Non-financial resources influencing internationalization decisions}

The majority of the participants indicated that their firms' smaller sizes, per se, did not affect their decisions to internationalize, stating that "no, size does not matter" and "internationalization is not only reserved for large firms." However, although small firms often face resource (i.e., financial, management, and information) constraints that limit their scope for international expansion, some participants considered the "orders at hand" as being equally important to their firms' sizes in ensuring internationalization success. From the 
participants' responses, it can be inferred that the firms' sizes played a pivotal role in determining the financial viability of their international transactions. This opinion stems from the participants' opinions that "large firms are better positioned to (i) participate in international market fairs, (ii) manage working capital (production capacity and equipment), (iii) vertically integrate their operations and (iv) respond to the changing needs of the foreign customers." These opinions led us to categorize non-financial resources into sub-themes, which we grouped as innovation capabilities, knowledge and networking, and production capacity.

The findings of this study thus confirm the claim in the literature that size is an important factor for SMEs' internationalization (Ojala \& Tyrvainen, 2007; Chelliah et al., 2010). Several studies, such as Cavusgil and Naor (1987) and Hozlmuller and Kasper (1991), have further confirmed that the size of firm significantly affects mode of entry decisions. For example, SMEs have a stronger tendency towards exporting activities than that of large sized firms (Abdul Talib \& Salleh, 1997). This may be explained by the fact that SMEs do not have enough resources to adopt other modes of entry such as Joint Ventures (JV) or Wholly Owned Subsidiary (WOS).

Theme 3.1: Innovation capabilities influencing internationalization decisions. The participants' responses suggest that innovation played a vital role in their initial internationalization decisions. Most of the participants created innovative internal transformation processes and products to ensure effective market penetration and market growth: "We re-engineered our processes to respond quickly to clients' demands" and "By being innovative we suggested new ideas (designs, fabrics) to clients." The majority of the participants also indicated that innovation engenders better performance in foreign textile markets and that they, therefore, kept up-todate with fashion trends and the latest production techniques: "It helped us to maintain our competitive edge." Nevertheless, innovation capabilities are largely dependent on firms' existing resources. The costs associated with product innovation and process innovation are significant in the textile manufacturing sector. For example, product innovation in this industry is not limited only to the creation of new and stylish models of clothing, but also includes the conception of new fabrics and materials to meet the needs of different markets. Moreover, continuous product innovation depends heavily on firms' abilities to establish the right ecosystem through the deployment of the right mix of resources in terms of research teams and equipment. It can be deduced from the participants' responses that due to the resource constraints associated with smaller firms, they did not engage in production innovation initiatives. This was demonstrated by the absence of dedicated 'research and development' (R\&D) teams in these firms. On the other hand, the participants were all prone to invest in process innovation with the objective of improving their operational efficiency. Due to resource limitations, process innovation in the form of re-engineered internal processes seems to have been the best strategy to ensure small firms' sustainability.

Overall, the information gained from the participants regarding their innovation capabilities supports claims made in the literature that larger firms are better positioned to engage in product innovation compared to their smaller counterparts. For example, Fang (2009) notes that larger firms increase the probability of product invention due to the existence of a threshold size for a firm to invest in product R\&D.

Theme 3.2: Knowledge and networking influencing internationalization decisions. The results revealed that the participants' initial lack of knowledge about international markets negatively influenced their decisions to internationalize: "We did not know anything about documentation 
for exports." However, their expertise in the textile industry, as well as the market information they obtained from Government-funded international market fairs, increased their levels of comfort to continue pursuing internationalization as a growth strategy: "Our participation in the trade fair has opened our doors to the international market." All of the firms started their first internationalization steps by responding to unsolicited orders, which stemmed from buyer-seller meetings and trade fairs. This led us to emphasize the importance of participation in trade fairs and that, without external funding support, the high costs associated with probing international markets and networking with potential clients can have serious limitation for the internationalization of small sized firms. Additionally, in terms of the participants' orientation towards knowledge enhancement, the analyses of their responses revealed that the Internet remains a cost-effective means of obtaining information about doing business internationally as well as foreign market opportunities.

Furthermore, the participants also acknowledged that networking with any person, body, or institution involved in international trading could enhance internationalization initiatives. However, most of the participants revealed that they did not have sufficient networks when they initially decided to internationalize: "We did not have any foreign personal contact." In this regard, all of the participants indicated that as they expanded their international operations, they also expanded their networks to include several stakeholders, such as clients, suppliers, local and foreign institutions, Ministries, and agents. These stakeholders are crucial for information purposes about the international markets, additional prospective clients, and future fashion trends, as well as the rules and procedures for conducting international transactions.

Despite some challenges revealed by the results pertaining to the participants' access to information and their networking capabilities, it would be inappropriate to assume, in this regard, that their smallness was a limiting factor.

Theme 3.3: Production capacity influencing internationalization decisions. All of the participants revealed that their size-related limited production capacities discouraged their initial decisions to internationalize: "We were lacking qualified personnel and equipment." However, they soon realized that when foreign clients trust that orders would be available within the prescribed timeframes, their capacities could be managed: "We worked in shifts to optimize space and capacity." Although the participants also revealed that their financial constraints, due to their smaller sizes, initially had a significant negative influence on their propensity to invest in the latest production equipment and techniques, their smaller sizes also gave them an advantage above larger firms. One participant pointed out that, due to their smaller size, "we were able to handle small orders with more varieties," something which some clients preferred and which larger firms are often reluctant to do. However, overall, the majority of the participants perceived their production capacity, due to their smallness, as a limitation for their growth in international markets, since "we were not able to take additional orders," and, thus, they could not benefit from economies of scale.

\section{Quantitative findings}

Although all 56 eligible medium-sized textile manufacturers in Mauritius were approached for the purpose of the quantitative data collection, only $43(77 \%)$ of the firms agreed to participate in this study. The applicable demographic profiles and patronage habits which 
were drawn from the 43 respondents revealed that, at the start-up phases of the firms, $65.12 \%$ $(\mathrm{n}=28)$ of them served only the domestic Mauritian market, with $34.88 \%(\mathrm{n}=15)$ serving both the domestic and international markets. However, 27 of the 28 firms that served only the domestic Mauritian market during their start-up phases revealed that they had envisioned themselves to internationalize in future. With all of the respondents currently serving international markets, the results further indicate that most of them $(95.35 \%, \mathrm{n}=41)$ internationalized in reaction to unsolicited orders during their start-up phases or some time thereafter, which they were exposed to during either buyer-seller meetings $(76.74 \%, \mathrm{n}=33)$ or trade shows $(18.64 \%, \mathrm{n}=8)$. This finding supports the findings in Theme 1 of the qualitative results (initial internationalization intentions). However, prior to their first international sales, only $25.58 \%(n=11)$ had already conducted country-specific market research and only $9.30 \%(n=4)$ had previously collaborated with foreign partners.

Furthermore, seven of the firms (16.28\%) indicated that they currently serve only international markets, while the rest of the respondents $(83.72 \%, \mathrm{n}=36)$ served both the domestic and international markets. While most of the firms export their products to between one and three foreign countries $(58.14 \% ; \mathrm{n}=25)$, sixteen firms $(37.21 \%)$ have expanded their export markets to between four and six countries, and two firms (4.65\%) already export to more than six countries. The main markets are Southern and Eastern Africa, Europe, the USA, Réunion Island, and Seychelles. As the firms expanded into international markets, they also opted for increased research and development (R\&D) activities to keep up with the latest fashion trends and technological advances. The results revealed that $37.21 \%(\mathrm{n}=16)$ of the respondents currently have $\mathrm{R} \& \mathrm{D}$ teams, and that these firms also conduct $\mathrm{R} \& \mathrm{D}$ activities more regularly than the firms without $\mathrm{R} \& \mathrm{D}$ teams.

\section{Psychometric properties of the measuring instrument}

The psychometric properties of the measuring instrument were examined by addressing its validity and reliability. To determine the validity of the questionnaire, we opted for factor analyses. From the results of the qualitative approach, all of the items in the questionnaire were divided into two categorical groupings, namely financial and non-financial resources. However, there was some uncertainty about the number of factors which may exist among the set of items in each grouping and, therefore, we conducted an exploratory factor analysis (EFA) as a data reduction method (Zikmund et al., 2013). Prior to the EFA, the suitability of the data for factor analysis was firstly assessed for each categorical grouping. The results revealed coefficients of 0.3 and higher in the correlation matrices, with favorable KMOvalues $(>0.5)$ and Bartlett's Test of Sphericity reaching $\mathrm{p} \approx 0.00$ in all instances, indicating that the data were well suited to be evaluated with factor analyses. Hereafter, all of the items were subjected to principal component analysis (PCA). Using Kaiser's criterion, only eigenvalues exceeding 1 were used to determine the number of factors to extract. From this reduction method, four factors referring to the size-related financial and non-financial resources which influence internationalization decisions were retained within the respective categorical groupings (see Table 1). Based on the factor analysis conducted on all of the questionnaire items, it can be concluded that the measuring instrument contains acceptable elements of validity. 
Table 1. Results from the exploratory factor analysis.

\begin{tabular}{|l|l|l|l|l|c|}
\hline $\begin{array}{l}\text { Categorical } \\
\text { groupings }\end{array}$ & KMO & $\begin{array}{l}\text { Bartlett's } \\
\text { test }(\boldsymbol{p})\end{array}$ & $\begin{array}{l}\text { Total variance } \\
\text { explained } \\
\text { (Eigenvalues >1) }\end{array}$ & Factors retained & $\begin{array}{l}\text { No. of } \\
\text { items }\end{array}$ \\
\hline $\begin{array}{l}\text { Financial } \\
\text { resources }\end{array}$ & 0.800 & 0.000 & $70.486 \%$ & $\begin{array}{l}\text { Government financial } \\
\text { support and utilization }\end{array}$ & 3 \\
\hline $\begin{array}{l}\text { Non- } \\
\text { financial } \\
\text { resources }\end{array}$ & 0.603 & 0.000 & $48.26 \%$ & Innovation capabilities & 9 \\
\cline { 2 - 6 } & 0.663 & 0.000 & $41.11 \%$ & $\begin{array}{l}\text { Managerial knowledge } \\
\text { and business } \\
\text { capabilities }\end{array}$ & 15 \\
\cline { 4 - 6 } & & & $\begin{array}{l}\text { Managerial } \\
\text { competencies and } \\
\text { operational } \\
\text { considerations }\end{array}$ & 7 \\
\hline
\end{tabular}

All of the extracted factors from the EFA were subsequently subjected to reliability testing to determine the internal consistency by means of Cronbach's alpha. Based on the Alpha values obtained from all of the factors, it can be concluded that all of the respective sections in the measuring instrument contain acceptable elements of reliability $(\alpha>0.75)$ (see Table 2$)$.

Table 2. Reliability of retained factors.

\begin{tabular}{|l|l|l|c|}
\hline Categorical groupings & Factors retained & No. of items & $\begin{array}{l}\text { Cronbach's } \\
\text { alpha }\end{array}$ \\
\hline Financial resources & $\begin{array}{l}\text { Government financial support } \\
\text { and utilization }\end{array}$ & 3 & 0.824 \\
\hline $\begin{array}{l}\text { Non-financial } \\
\text { resources }\end{array}$ & Innovation capabilities & 9 & 0.758 \\
\cline { 2 - 4 } & $\begin{array}{l}\text { Managerial knowledge and } \\
\text { business capabilities }\end{array}$ & 15 & 0.863 \\
\cline { 2 - 4 } & $\begin{array}{l}\text { Managerial competencies and } \\
\text { operational considerations }\end{array}$ & 7 & 0.774 \\
\hline
\end{tabular}

Based on the retained factors identified, descriptive statistics were subsequently used to summarize the results and to provide an effectual representation of the respondents' perceptions of size-related financial and non-financial resources influencing their firms' internationalization activities. Two descriptive statistical techniques were used in this regard, namely the mean scores $(\bar{x})$ and standard deviations $(\sigma)$. Based on the statements in the questionnaire, the respondents had to indicate the importance of each item relating to the size of their firms on a five-point Likert scale, where $1=$ least important and $5=$ very important. In the following discussion, the results are reported in terms of the mean scores $(\overline{\mathbf{x}})$ and standard deviations $(\sigma)$. Since the Likert scale has specific ratings at levels 1 and 5, we decided to use the following ranges of mean score results within the ratings as guidelines for reporting purposes:

- Not important: $1 \leq$ mean score $<2$

- Slightly important: $2 \leq$ mean score $<3$

- Relatively important: $3 \leq$ mean score $<4$

- Important: $4 \leq$ mean score $\leq 5$ 
Financial resources influencing internationalization decisions

The mean scores $(\overline{\mathbf{x}})$ and standard deviations $(\boldsymbol{\sigma})$ obtained from the three individual statements measuring the importance of government financial support in encouraging internationalization are summarized in Table 3.

Table 3. Importance of government financial support in encouraging internationalization.

\begin{tabular}{|l|l|l|l|}
\hline Items & $\mathbf{n}$ & $\overline{\mathbf{x}}$ & $\mathbf{\sigma}$ \\
\hline Government guaranteeing the loans under specific conditions & 43 & 4.16 & 0.574 \\
\hline Government providing (part) financing for employees' training & 43 & 3.49 & 0.827 \\
\hline $\begin{array}{l}\text { Government providing bridging loans to overcome short-term } \\
\text { cash flow problems }\end{array}$ & 43 & 4.30 & 0.599 \\
\hline Overall mean score & $\mathbf{4 3}$ & $\mathbf{3 . 9 8}$ & $\mathbf{0 . 6 6 6}$ \\
\hline
\end{tabular}

Although the qualitative results indicated that the participants preferred financial support from their retail banks, the quantitative results in Table 3 indicate that the respondents perceive government financial support as a relatively important resource to finance their internationalization $(\bar{x}=3.98 ; \sigma=0.666)$. This finding is consistent with Shamsuddoha, Ali, and Ndubisi's (2009) study, which concluded that market developmentrelated government assistance significantly influences SMEs' internationalization. In terms of their financial needs, the respondents perceived government bridging loans as the most important financial support to overcome short-term cash flow problems $(\bar{x}=4.30 ; \sigma=$ $0.599)$, while they agreed least with the utilization of funds for training purposes $(\bar{x}=3.49$; $\sigma=0.827$; 'relatively important'). These findings extend on the qualitative findings of Theme 2 (financial resources influencing internationalization decisions).

Non-financial resources influencing internationalization decisions

The non-financial resources, which influence internationalization decisions, were divided into three categories, namely managerial knowledge and business capabilities, operational considerations, and innovation capabilities.

Innovation capabilities. The mean scores $(\overline{\mathrm{x}})$ and standard deviations $(\sigma)$ obtained from the nine individual items measuring the importance of innovation capabilities in obtaining foreign orders are summarized in Table 4.

Overall, the respondents indicated that innovation $(\bar{x}=4.02 ; \sigma=0.797)$ is important in obtaining foreign orders. Although all the statements in this category measured positively $(\geq 3)$, the respondents agreed the most with the statement "Establishing good relations with suppliers" ( $\bar{x}=4.42 ; \sigma=0.587$; 'important action'). The respondents agreed least with the statement "Encouraging key employees to visit foreign clients" ( $\bar{x}=3.07 ; \sigma=0936$; 'relatively important action'). These findings extend on the findings in Theme 3.1 of the qualitative results (innovation capabilities influencing internationalization decisions). 
Table 4. Importance of innovation capabilities in obtaining foreign orders among 43 firms.

\begin{tabular}{|l|l|l|}
\hline Items & $\overline{\mathbf{x}}$ & $\boldsymbol{\sigma}$ \\
\hline Establishing good relations with suppliers & 4.42 & 0.587 \\
\hline Searching for new markets & 4.14 & 0.743 \\
\hline Attending international market trade fairs & 4.28 & 0.701 \\
\hline Collecting information on foreign market trends & 4.19 & 0.627 \\
\hline Proposing new models to clients & 4.00 & 0.976 \\
\hline Developing linkages with international business network & 3.84 & 0.924 \\
\hline Encouraging key employees to visit foreign clients & 3.07 & 0.936 \\
\hline Visiting foreign clients & 4.16 & 0.814 \\
\hline Encouraging clients to visit the firm & 4.05 & 0.872 \\
\hline Overall mean score & $\mathbf{4 . 0 2}$ & $\mathbf{0 . 7 9 7}$ \\
\hline
\end{tabular}

Managerial knowledge and business capabilities. The mean scores $(\overline{\mathrm{x}})$ and standard deviations $(\sigma)$ obtained from the 15 individual items measuring the importance of managerial knowledge and business capabilities as consideration factors to internationalize are summarized in Table 5 .

Table 5. Importance of managerial knowledge and business capabilities as internationalization consideration factors among 43 firms.

\begin{tabular}{|l|l|l|}
\hline Items & $\overline{\mathbf{x}}$ & $\boldsymbol{\sigma}$ \\
\hline Flexibility in adapting to foreign market conditions & 4.26 & 0.658 \\
\hline Management's familiarity in conducting foreign transactions & 3.86 & 0.743 \\
\hline Management's network in motivating firms to go international & 3.86 & 0.675 \\
\hline Firm's reputation among foreign customers & 4.26 & 0.658 \\
\hline Management's strong interest to international market & 4.16 & 0.615 \\
\hline Management's knowledge of international markets & 3.98 & 0.831 \\
\hline Motivating firms to go international & 4.44 & 0.629 \\
\hline Strong finance position & 4.74 & 0.441 \\
\hline Decision-maker's personal network with customers & 4.23 & 0.718 \\
\hline Decision-maker's good command of the client's language & 3.86 & 0.743 \\
\hline Quality products & 4.88 & 0.391 \\
\hline Production capacity in motivating firms to go international & 4.07 & 0.669 \\
\hline Skilled human resources & 4.28 & 0.666 \\
\hline Customer-centric approach & 4.35 & 0.613 \\
\hline Decision-maker's personal network with agents & 3.81 & 0.699 \\
\hline Overall mean score & $\mathbf{4 . 2 0}$ & $\mathbf{0 . 6 4 9}$ \\
\hline
\end{tabular}

Overall, the respondents indicated that managerial knowledge and business capabilities are important consideration factors influencing their decisions to internationalize $(\bar{x}$

$=4.88 ; \sigma=0.391$; 'important consideration factor') and the least with the "Decision-maker's 
personal network with agents" $(\bar{x}=3.81 ; \sigma=0.699$; 'relatively important consideration factor'). These findings support the findings in Theme 3.3 of the qualitative results (production capacity influencing internationalization decisions).

Managerial competencies and operational aspects. The mean scores $(\bar{x})$ and standard deviations $(\sigma)$ obtained from the seven individual items measuring the importance of operational considerations and managerial competencies in decisions to internationalize are summarized in Table 6.

Table 6. Importance of managerial competencies and operational aspects when considering internationalization among 43 firms.

\begin{tabular}{|l|l|l|}
\hline Items & $\overline{\mathbf{x}}$ & $\mathbf{\sigma}$ \\
\hline Investment in latest machinery and equipment & 4.00 & 0.951 \\
\hline Special management skills/talents/time & 3.84 & 0.924 \\
\hline Decision-maker's knowledge of the foreign market & 4.16 & 0.754 \\
\hline Management's international experience & 3.30 & 1.036 \\
\hline Research and Development (R\&D) & 4.00 & 0.816 \\
\hline Size of the firm as a motivator to internationalize & 3.02 & 0.913 \\
\hline $\begin{array}{l}\text { Decision-maker's membership/affiliation to international } \\
\text { organization }\end{array}$ & 3.05 & 1.068 \\
\hline Overall mean score & $\mathbf{3 . 6 2}$ & $\mathbf{0 . 9 2 3}$ \\
\hline
\end{tabular}

Overall, the respondents indicated that the managerial competencies and operational aspects are relatively important considerations $(\bar{x}=3.62 ; \sigma=0.923)$ when deciding to internationalize. Although all the statements in this category also measured positively $(\geq 3)$, the respondents agreed most with "Decision-maker's knowledge of the foreign markets" $(\bar{x}$ $=4.16 ; \sigma=0.754$; 'important consideration factor'). In addition, the respondents agreed the least with the "Size of the firm as a motivator to internationalize" $(\bar{x}=3.02 ; \sigma=0.913$; 'relatively important consideration factor').

An interesting finding was that, although it was reported earlier that only $37.21 \%$ of the firms have $R \& D$ teams, the respondents regard $R \& D$ as an important factor $(\bar{x}=4.00 ; \sigma=$ $0.816)$ to consider during internationalization. This finding extends on the findings in Theme 3.2 of the qualitative results (knowledge and networking influencing internationalization decisions).

\section{Conclusions and recommendations}

Although most Mauritian textile manufacturers start their operations as small firms without initial intentions to internationalize, their overall sizes are not the pertinent reason for their reluctance to enter international markets. As with many other SIDS, Mauritius is ring-fenced from easy access to mainland economies and, therefore, the importance of SME participation in government-funded buyer-and-seller meetings and trade fairs is emphasized. The opportunities for international growth and the firms' sustainability depend largely on the unsolicited orders they obtain from foreign clients at these meetings and fairs.

However, despite access to possible unsolicited orders, many SIDS-based small firms remain discouraged to internationalize due to size-related factors such as available financial 
and non-financial resources. For these firms, accessing information, creating networks, seeking financial support, increasing capacity and capabilities, and investing in updated equipment either create opportunities for internationalization or barriers they need to overcome. Regardless, these factors are not always the main barriers that SIDS-based small firms face. Ultimately, their internationalization efforts and success depend largely on the intentions and overall motivation of managers to strategize international growth. In this research, all of the participants and respondents revealed that they were initially reluctant to internationalize but gained international success and overcame their limitations and barriers through perseverance and motivation. Eventually, the size-related factors, which initially hindered their intentions to internationalize, gave way to their firms' growth and sustainability.

\section{Limitations of this research}

No research is without limitations, and in this research the limitations revolved mostly around time constraints and funding availability. Due to limited funding, this research could only include internationalized, medium-sized Mauritian textile manufacturers, thereby excluding small and large textile manufacturers as well as all non-internationalized textile manufacturers. The available funding also limited the research to focus solely on the Mauritian context, thereby excluding other SIDS facing similar challenges.

Although a census of all the applicable textile manufacturers was used to collect data and the resulting population size was relatively small, it was quite difficult for us to gain access to all of the firms. We had to adapt to the managers' schedules and, since we physically visited all of the firms, which are geographically scattered across the island, it resulted in both the qualitative and quantitative data being collected over a long period. It was also daunting to convince some of the managers to contribute to this research, and 13 managers did not respond to any of our recruitment efforts.

In addition, the absence of more recent secondary information on the status and evolution of the SME sector in SIDS made it challenging for us to find theoretical evidence to compare with our empirical results.

\section{Recommendations for future research}

Future research can, while noting the above-mentioned limitations, include:

\section{Investigation of internationalization in other SIDS}

Although SIDS economies often face similar economic, environmental, and developmental challenges, the eco-systems in which SMEs evolve are not the same across SIDS. Therefore, future research including SMEs from other and additional SIDS will create opportunities for comparisons and, ultimately, the understanding of the size-related internationalization challenges faced by SMEs in SIDS economies.

\section{Small and large textile manufacturers in Mauritius}

While this research has focused only on medium-sized textile manufacturers in Mauritius, future studies can also be conducted to understand the size-related challenges of SIDS-based 
small and/or large firms. This will assist managers to develop appropriate internationalization strategies throughout the different stages of their firms' growth.

Considering other factors affecting internationalization of SMEs

It is acknowledged that this study could not have included all of the factors affecting SMEs' internationalization, such as entrepreneurial risk attitudes towards internationalization and the cultural dimension affecting internationalization of SMEs, among others. Since this research was conducted in a specific cultural setting, future research can also investigate how pertinent issues such as cultural dimension and risk attitude may influence the internationalization of SMEs in SIDS.

\section{References}

Abdul Talib, A.N., \& Salleh, M.F. (1997). Firm size and export attitudes of Malaysian exporters. In M. Sulaiman (Ed.), Proceedings of the second Asian Academy of Management Conference: Towards management excellence in the 21st century Asia (pp. 403-408). University of Science Malaysia.

Aghion, P., Askenazy, P., Berman, N., Cette, G., \& Eymard, L. (2012). Credit constraints and the cyclicality of R\&D investment: Evidence from France. Journal of the European Economic Association, 10(5), 1001-1024. https://doi.org/10.1111/j.1542-4774.2012.01093.x

Alvarez, R.E. (2004). Sources of export success in Small and Medium-Sized Enterprises: the impact of public programs. International Business Review, 13(3), 383-402. https://doi.org/10.1016/j.ibusrev.2004.01.002

Archer, L.T, Sharma, P., \& Su, J.J. (2020). Do credit constraints always impede innovation? Empirical evidence from Vietnamese SMEs. Applied Economics, 52(44), 4864-4880. https://doi.org/10.1080/00036846.2020.1751049

Ary, D., Jacobs, L.C., Irvine, C.K.S., \& Walker, D.A. (2019). Introduction to research in education (10th ed.). Cengage Learning.

Babin, B.J., \& Zikmund, W. (2016). Exploring marketing research (11th ed.). Cengage Learning.

Balboni, B., Bortoluzzi, G., \& Grandinetti, R. (2013). On the relationship between size, capabilities and internationalization: An explorative analysis of Italian subcontracting SMEs. International Journal of Globalisation and Small Business, 5(1/2), 114-132. https://doi.org/10.1504/ijgsb.2013.050489

Baldacchino, L., Cassar, V., \& Caruana, A. (2008). Start-up Success in a small island state: A study among entrepreneurs in Malta. Island Studies Journal, 3(1), 73-96.

Barney, J. (1991). Firm resources and sustained competitive advantage. Journal of Management, 17(1), 99-120. https://doi.org/10.1177/014920639101700108

Bezuidenhout, M.J. (2005). A guide for accreditation reviews aimed at quality assurance in South African undergraduate medical education and training (Unpublished $\mathrm{PhD}$ Dissertation, University of Bloemfontein, South Africa). https://doi.org/10.4314/sajhe.v21i5.50273

Brink, H.I.L. (1993). Validity and reliability in qualitative research. Curationist, 16(2), 35-38. Bukve, O. (2019). Designing social science research. Palgrave Macmillan.

Caiazza, R., \& Volpe, T. (2013). How Campanian small and medium enterprises (SMEs) can compete in the global Agro-food industry. Journal of Food Products Marketing, 19(5), 406412. https://doi.org/10.1080/10454446.2013.807413 
Calcagnini, G., \& Favaretto, I. (2012). Small businesses in the aftermath of the crisis: International analyses and policies. Springer.

Cavusgil, S.T., \& Naor, J. (1987). Firm and management characteristics as discriminators of export marketing activity. Journal of Business Research, 15(3), 221-235. https://doi.org/10.1016/0148-2963(87)90025-7

Chelliah, S., Pandian, S., Sulaiman, M., \& Munusamy, J. (2010). The moderating effect of firm size: Internationalization of small and medium enterprises (SMEs) in the manufacturing sector. African Journal of Business Management, 4(14), 3096-3109.

Chen, J., Sousa, C.M.P., \& He, X. (2016). The determinants of export performance: A review of the literature 2006-2014. International Marketing Review, 33(5), 626-670. https://doi.org/10.1108/imr-10-2015-0212

Coe, N., \& Jones, A. (2010). The economic geography of the UK. Sage.

Costa, E., Soares, A.L., \& De Sousa, J.P. (2016). Information, knowledge and collaboration management in the internationalization of SMEs: A systematic literature review. International Journal of Information Management, 36(4), 557-569. https://doi.org/10.1016/j.ijinfomgt.2016.03.007

Creswell, J.W., \& Creswell, J.D. (2018). Research design: Qualitative, quantitative, and mixed methods approaches (5th ed.). Sage.

Creswell, J.W., \& Plano Clark, V.L. (2017). Designing and conducting mixed methods research (3rd ed.). Sage.

Das, T.K. (2015). Strategic alliances for SME development. Information Age.

Dominguez, N., \& Mayrhofer, U. (2018). Key success factors of SME internationalization: A cross-country perspective. International Business and Management, 34, 121-136. https://doi.org/10.1108/s1876-066x201834

Economic Development Board. (2018). Opportunities. https://www.edbmauritius.org/manufacturing-traditional-industries

Enterprise Mauritius. (2017). Report on Mauritian textile and apparel sector. http://www.enterprisemauritius.biz

Fang, X. (2009). Process innovation, product innovation and firm size. Doctoral thesis, University of Illinois at Chicago.

Fernandez-Olmos, M., \& D'iez-Vial, I. (2013). The direct or indirect exporting decision in Agri-food firms. Agribusiness International Journal, 30(2), 148-164. https://doi.org/10.1002/agr.21360

Ferreira, M., Eiriz, V., \& Soares, A. (2013). The impact of market-related factors on the entry mode of Small and Medium Enterprises. Journal of Transnational Management, 18(4), 273291. https://doi.org/10.1080/15475778.2013.840464

Fusch, P.I., \& Ness, L.R. (2015). Are we there yet? Data saturation in qualitative research. The Qualitative Report, 20(9), 1408-1416.

García-Quevedo, J., Segarra-Blasco, A., \& Teruel, M. (2018). Financial constraints and the failure of innovation projects. Technological Forecasting and Social Change, 127, 127-140. https://doi.org/10.1016/j.techfore.2017.05.029

Gubik, A.S., \& Karajz, S. (2014). The choice of foreign market entry modes: The role of resources and industrial driving forces. Entrepreneurial Business and Economics Review, 2(1), 49-63. https://doi.org/10.15678/eber.2014.020105 
Hamilton, L., \& Webster, P. (2015). The international business environment (3rd ed.). Oxford University Press.

Hill, C.W.L. (2017). International business: Competing in the global marketplace (9th ed.). McGraw Hill. Hollensen, S. (2014). Global marketing (6th ed.). Pearson.

Hopkins, R.A. (2017). Grow your global markets: A handbook for successful market entry. Springer. https://doi.org/10.1007/978-1-4842-3114-2 15

Hozlmuller, H.H., \& Kasper, H. (1991). On a theory of export performance. Management International Review, 31, 45-70.

Jaklič, A., \& Svetličič, M. (2017). Enhanced transition through outward internationalization: Outward FDI by Slovenian firms. Routledge. https://doi.org/10.4324/9781315190952

Jones, M.V., Dimatratos, P., Fletcher, M., \& Young, S. (2009). Internationalization, entrepreneurship and the smaller firm: Evidence from around the world. Edward Elgar.

Kalinic, I., \& Forza, C. (2012). Rapid internationalization of traditional SMEs: Between gradualist models and born globals. International Business Review, 21(4), 694-707. https://doi.org/10.1016/j.ibusrev.2011.08.002

Karasavvoglou, A., \& Polychronidou, P. (2017). Agricultural sector issues in the European periphery: Productivity, export and development challenges. Vernon Press.

Kellermanns, F.W., \& Hoy, F. (2016). The Routledge companion to family business. Routledge.

Kolb, B. (2017). Marketing research: A concise introduction (2nd ed.). Sage.

Korstjensa, I., \& Moserb, A. (2018). Series: Practical guidance to qualitative research. Part 4: Trustworthiness and publishing. European Journal of General Practice, 24(1), 120-124. https://doi.org/10.1080/13814788.2017.1375092

Kruasom, T. (2017). Creating a competitive advantage for Thai SMEs towards Thailand 4.0 era. KKBS Journal of Business Administration and Accountancy, 1(1), 1-20.

Kyvik, O. (2011). Internationalization of small firms: The importance of a global mindset. International Journal of Technology, Transfer and Commercialisation, 10(3/4), 314-331. https://doi.org/10.1504/ijttc.2011.040893

Lakew, Y.D. (2015). Determinants and impediments in the internationalization process of Small and Medium-Sized manufacturing enterprises in Ethiopia. Unpublished $\mathrm{PhD}$ Dissertation, University of South Africa.

Laufs, K., \& Schwens, C. (2014). Foreign market entry mode choice of Small and MediumSized Enterprises: A systematic review and future research agenda. International Business Review, 23(6), 1109-1126. https://doi.org/10.1016/j.ibusrev.2014.03.006

Linder, D., \& Leyh, C. (2018, July 18-20). Organisation in transformation: Agility as consequence or prerequisite of digitization. In W. Abramowicz \& A. Paschke (Eds.), Proceedings of the 21st International Conference on Business Information Systems (pp. 86-101). Springer. https://doi.org/10.1007/978-3-319-93931-5 7

Madani, A.E. (2018). SME policy: Comparative analysis of SME definitions. International Journal of Academic Research in Business and Social Sciences, 8(8), 103-114. https://doi.org/10.6007/ijarbss/v8-i8/4443

Malhotra, N.K. (2010). Marketing research: An applied orientation (6th ed.). Pearson.

Maree, K. (2016). First steps in research (2nd ed.). Van Schaik.

Maumbe, B., \& Okello, J.J. (2013). Technology, sustainability and rural development in Africa. IGI Global. 
Mauritius Export Association. (2017). The reusable annual report 2017. https://mexamauritius.org/sites/default/files/MEXA\%20AR\%202017.pdf

Ministry of Business, Enterprise, and Cooperatives (2018). 10-Year master plan for the SME sector in Mauritius, accelerated SME innovation $\mathcal{E}$ growth. https://enterbusiness.govmu.org/SiteAssets/MofedStyles/Documents/SME\%20Maste r\%20Plan Full\%20Version FINAL.pdf

Ministry of Finance and Economic Development (2018). Supplement to the budget 2018/2019. Pursuing our transformative journey. http://budget.mof.govmu.org/budget201819/2018 19budgetsupplement.pdf

Mitomo, H., Fuke, H., \& Bohlin, E. (2015). The smart revolution towards the sustainable digital society: Beyond the era of convergence. Edward Elgar. https://doi.org/10.4337/9781784710040

Morse, J.M., \& Field, P.A. (1996). Nursing research: The application of qualitative approaches (2nd ed.). Stanley Thomas.

Morse, J.M., Barrett, M., Mayan, M., Olson, K., \& Spiers, J. (2002). Verification strategies for establishing reliability and validity in qualitative research. International Journal of Qualitative Methods, 1(2), 13-22. https://doi.org/10.1177/160940690200100202

Narayanan, V. (2015). Export barriers for small- and medium-sized enterprises: A literature review based on Leonidou's model. Entrepreneurial Business and Economics Review, 3(2), 105-123. https://doi.org/10.15678/eber.2015.030208

National Export Strategy (2017). Mauritius national export strategy 2017-2021. https://industry.govmu.org/Documents/NES/1 Mauritius\%20National\%20Export\% 20Strategy web.pdf

O'Keeffe, J., Buytaert, W., Mijic, A., Brozovic, N., \& Sinha, R. (2016). The use of semistructured interviews for the characterization of farmer irrigation practices. Hydrology and Earth System Sciences, 20, 1911-1924. https://doi.org/10.5194/hess-20-1911-2016

Organization for Economic Co-operation and Development (2011). Intellectual assets and innovation. The SME dimension. OECD Studies on SMEs and Entrepreneurship. https://doi.org/10.1787/9789264118263-en

Organization for Economic Co-operation and Development (2009). Top barriers and drivers to SME internationalization (Report by the OECD working party on SMEs and entrepreneurship). http://www.oecd.org/cfe/smes/43357832.pdf

Ojala, A., \& Tyrvainen, P. (2007). Market entry and priority of small and medium-sized enterprises in the software industry: An empirical analysis of cultural distance, geographic distance, and market size. Journal of International Marketing, 15(3), 123-149. https://doi.org/10.1509/jimk.15.3.123

Olejnik, E. (2014). International small and medium-sized enterprises: Internationalization patterns, mode changes, configurations and success factors. Springer.

Onwuegbuzie, A.J., \& Collins, K. (2017). The role of sampling in mixed methods-research. Kölner Zeitschrift für Soziologie \& Sozialpsychologie, 69, 133-156. https://doi.org/10.1007/s11577-017-0455-0

Patten, M.L., \& Newhart, M. (2018). Understanding research methods: An overview of the essentials (10th ed.). Routledge. 
Peng, M.W. (2001). The resource-based view and international business. Journal of Management, 27(6), 803-829.

Penrose, E. (1959). The theory of the growth of the firm. Basil Blackwell.

Polit, D.F., \& Beck, C.T. (2012). Nursing research: Generating and assessing evidence for nursing practice (9th ed.). Lippincott Williams \& Wilkins.

Profetto-McGrath, J., Polit, D.F., \& Beck, C.T. (2010). Canadian essentials of nursing research. Lippincott Williams \& Wilkins.

Reddy, M. (2007). Small business in small economies: constraints and opportunities for growth. Social and Economic Studies, 56, 304-321.

Ruzzier, M., \& Ruzzier, M.K. (2015). On the relationship between firm size, resources, age at entry and internationalization: The case of Slovenian SMEs. Journal of Business Economics and Management, 16(1), 52-73. https://doi.org/10.3846/16111699.2012.745812

Ruzzier, M., Antončič, B., Hisrich, R.D., \& Konečnik, M. (2007). Human capital and SME internationalization: A structural equation modelling study. Canadian Journal of Administrative Science, 24(1), 15-29. https://doi.org/10.1002/cjas.3

Schwester, R.W. (2015). Teaching research methods in Public Administration. IGI Global.

Sekaran, U., \& Bougie, R. (2016). Research methods for business: A skill-building approach. John Wiley \& Sons.

Shafaeddin, M. (2014). Competitiveness and development: Myth and realities. Anthem Press.

Shamsuddoha, A.K., Ali, M.Y., \& Ndubisi, N.O. (2009). Impact of government export assistance on internationalization of SMEs from developing nations. Journal of Enterprise Information Management, 22(4), 408-422. https://doi.org/10.1108/17410390910975022

Shariff, M.N.M., Ahmad, R.N., \& Shabir, M.S. (2020). Moderating effect of access to finance of the gem and jewelry industry. Utopía y Praxis Latinoamericana, 25(2), 264-279.

Shazia, S. (2014). Self-concept, learning styles, study habits and academic achievement of adolescence in Kashmir. Anchor Academic Publishing.

Shenton, A.K. (2004). Strategies for ensuring trustworthiness in qualitative research projects. Education for Information, 22(2), 63-75. https://doi.org/10.3233/efi-2004-22201

Silva, F., \& Carreira, C. (2012). Do financial constraints threat the innovation process? Evidence from Portuguese firms. Economics of Innovation and New Technology, 21(8), 701736. https://doi.org/10.1080/10438599.2011.63997

Singh, D. (2009). Export performance of emerging market firms. International Business Review, 18, 321-330. https://doi.org/10.1016/j.ibusrev.2009.03.002

Singh, G., Pathak, R.D., \& Naz, R. (2010). Issues faced by SMEs in the internationalization process: Results from Fiji and Samoa. International Journal of Emerging Markets, 5(2), 153 182. https://doi.org/10.1108/17468801011031801

Small and Medium Enterprises Development Authority (2009). Act 2009. Act No. 18 of 2009. https://www.ilo.org/dyn/natlex/docs/ELECTRONIC/82663/90714/F1619164235 /MUS82663.pdf

Sousa, C.M.P., Martínez-López, F.J., \& Coelho, F. (2008). The determinants of export performance: A review of the research in the literature between 1998 and 2005. International Journal of Management Reviews, 10(4), 343-374.

Statistics Mauritius. (2018). Publications on the social and economic indicators. http://statsmauritius.govmu.org 
Statistics Mauritius (2020). Monthly external merchandise trade statistics, May 2020. https://statsmauritius.govmu.org/Documents/Statistics/Monthly/Trade/2020/Trade M May20.pdf

Tang, Y.K. (2011). The influence of networking on the internationalization of SMEs: Evidence from internationalized Chinese firms. International Small Business Journal, 29(4), 374-398. https://doi.org/10.1177/0266242610369748

Vazquez-Brust, D.A., Sarkis, J., \& Cordeiro, J.J. (2013). Collaboration for sustainability and innovation: A role for sustainability driven by the global south?. Springer. https://doi.org/10.1007/978-94-007-7633-3

Vemic, M. (2019). Strategic optimization of medium-sized enterprises in the global market. IGI Global. World Bank Group (2019). The World Bank in small states. https://www.worldbank.org/en/country/smallstates/overview

Xin, K., Sun, Y., Zhang, R., \& Liu. X. (2019). Debt financing and technological innovation: Evidence from China. Journal of Business Economics and Management, 20(5), 841-859. https://doi.org/10.3846/jbem.2019.10185

Zikmund, W.G., Babin, B.J., Carr, J.C., \& Griffin, M. (2013). Business research methods (9th ed.). South-Western Cengage Learning. 